\title{
OPTIMIZATION OF UKRAINIAN ECONOMY STRUCTURE
}

\author{
Anatolii BOBROVYTSKYI \\ Taras Shevchenko National University of Kyiv, Ukraine \\ temsweden@gmail.com
}

\begin{abstract}
The structure of the economy is a key indicator of its development Research trends changes in the structure is the subject of many studies of western and domestic researchers to accelerate and optimize the development of the economies, increase their competitiveness and tracking global development processes. The publication is dedicated to the process of tracking changes in the structure of Ukraine's economy and forecasting of medium- and long-term prospects of its development within the framework of integration into the world economic space. Detailed attention is devoted to the prediction of each of the key economic sectors of Ukraine.
\end{abstract}

Key words: economy structure, main sectors of national economy, industrial sector, services, agro-sector, branch structure of economy, territorial structure of economy.

UDC: 911.3

\section{ОПТИМІЗАЦІЯ СТРУКТУРИ ЕКОНОМІКИ УКРАїНИ}

\author{
Анатолій БОБРОвИцький \\ Київський національний університет імені Тараса Шевченка, Україна \\ temsweden@gmail.com
}

\begin{abstract}
Анотація: Структура економіки країни $\epsilon$ ключовим показником її розвитку. Дослідження тенденцій змін структури $\epsilon$ предметом багатьох досліджень західних та вітчизняних дослідників для прискорення та оптимізації розвитку економік, підвищення їх конкурентності та відслідковування глобальних процесів розвитку. Публікація присвячена відстеженню процесу зміни в структурі економіки України та середньо і довгострокового прогнозування перспективи її розвитку в рамках інтеграції в світовий економічний простір. Детальна увага присвячена прогнозуванню розвитку кожного з ключових секторів економіки України.
\end{abstract}

Ключові слова: структура економіки, основні сектори економіки, промисловий сектор, сектор послуг, сектор сільського господарства, галузева структура, територіальна структура.

удк: 911.3

Вступ. Постановка проблеми. Економіка незалежної України є спадком частини економіки СРСР, що не відповідала за своєю структурою незалежній ринковій економіці, яка б забезпечувала сталий розвиток незалежної країни у відповідності до показників, що характеризують розвинені економіки. Структура економіки України формувалась за відсутності внутрішньої конкуренції, домінувала одна форма власності. Структура економіки покликана забезпечити конкурентоздатність країни та економічний фундамент для більш активної позиції в глобальному економічному та політичному житті світу.

Для забезпечення процесу інтеграції до Європейського Союзу насамперед, та інтеграції в світовий економічний простір, необхідним та безумовним $є$ адаптація структурних змін економіки країни та здійснення відповідних кроків щодо реформування управління економікою 3 метою надання пріоритетності розвитку галузям, які забезпечують найвищий рівень доданої вартості та $є$ конкурентоспроможними на регіональних та глобальних товарних ринках.

Галузева та регіональна структури економіки мають можливості розвитку, зважаючи на наявність

(C) А. Бобровицький

природно-кліматичних, людських ресурсів, відповідний розвиток транспортної інфраструктури тощо. Однак, незважаючи, на більш ніж 20 річну історію розвитку незалежної України суттєвих успіхів та досягнень в удосконаленні структури економіки України не відбулося. Виникає закономірне запитання: чому?

Аналіз останніх досліджень та публікацій. Дослідженню структури економіки України, як галузевої так і регіональної, присвячено багато наукових досліджень. Вказане питання розглядалось в різних напрямках, досліджувався вплив тих чи інших факторів на процеси, що відбуваються в економіці, але суттєвого впливу на розвиток останньої до цього часу не спостерігається. Негативні тенденції або зберігаються, або навіть посилюються, негативно впливають на рівень життя в країні, iї положення в системі глобального та регіонального географічного поділу праці та ведуть до інших наслідків, результатом яких $\epsilon$ заморожування розвитку або прихований чи явний регрес.

Серед вітчизняних дослідників слід виділити фундаментальні праці економістів та економіко-географів ОлійникаЯ.Б., Топчієва О.Г., Гальчинського А.С., ГеєцяВ.М. та інших учених, що досліджують більш вузькі аспекти структури економіки України. Серед зарубіжних учених 
важливе місце мають роботи Р.Кларка (теорія циклічних та структурних трансформацій економіки), А.Тоффлера (теорія трьох хвиль), Д.Белла та А. Туррена (теорія постіндустріального суспільства), П.Друкера (концепція нового та інформаційного суспільства) та інші. Важливість досліджень структури економіки полягає в розробці методології досліджень та їх інструментарію, що дає можливість створювати як статичні, так і динамічні моделі розвитку структури економіки різних країн та їх взаємодію на регіональному та глобальному рівнях.

Формування цілей статті. Досягнення поставлених цілей зумовлює серйозні зміни та підходи досліджень на макроекономічному рівні 3 використанням методик, що дозволяють створювати порівняльні моделі змін структури економіки. Проведені дослідження оптимізації структури економік розвинених країн, країн, що розвиваються та країн з перехідними економіками. Моделі структури економік розвинених країн $є$ еталонними та служать зразками для прогнозування структурних змін в економіках країн з перехідними економіками. Цілями нашого дослідження є розгляд варіантів змін структури економіки України для досягнення поступального розвитку та збільшення як внутрішнього валового продукту країни, так i валової добавленої вартості галузей промисловості, що характеризувало б підвищення продуктивності праці, гармонізацію територіальної структури, використання трудових ресурсів та інтелектуального потенціалу країни.

Важливою є класифікація чинників, що мають рушійний вплив на розвиток економіки України, як економічного і соціального, так і політичного характеру, та оцінка динамічних змін їх впливу на сталий розвиток економіки України через удосконалення її структури.

Окрім визначення основних чинників, ціллю дослідження $є$ аналіз та можливий прогноз змін у структурі економіки із застосуванням когнітивного підходу

Виклад основного матеріалу. Генералізація у підходах до вивчення структурних змін знайшла відображення в ключових теоріях розвитку структури економіки.

Серед теорій, які протягом десятиліть знаходили своє практичне підтвердження слід виділити: теорію «трьох секторів» англійського економіста Коліна Кларка, у відповідності з якою відбуваються послідовні зміни трьох основних секторів у структурі економіки: первинного - видобутку та виробництва сировини, вторинного - переробної промисловості і третинного - обслуговуючого (сфера послуг, науки та відтворення людських ресурсів). Вчений стверджував, що кожний із секторів має свій життєвий цикл і структура економіки варіюється у залежності від співвідношень циклів. Вказана теорія успішно використовувалась для аналізу структурних змін економік країн та до цього часу використовується у якості інструментарію досліджень економік на країновому рівні.
Однією 3 найпоширеніших теорій $€$ теорія професора Станфордського університету Пола Ромера - «Нова теорія зростання» [10, с. 79], що як основні чинники зростання розглядає не екзогенні фактори зовнішнього впливу на зміну структури економіки, а саме «ендогенні» фактори або технологічне оновлення виробництв, що $є$ ринковим та конкурентним стимулом розвитку. Опосередкованим висновком вказаної теорії $\epsilon$ те, що економічне зростання $\epsilon$ наслідком прискореного зростання галузей, пов'язаних з розвитком та розповсюдженням знань. Ці та ряд інших теорій циклічних змін у розвитку структури економік є важливим інструментом для дослідження динаміки змін в українській економіці.

В таких дослідженнях також доцільно використовувати методологію OECD, що передбачає виділення у структурі економіки країни 5 стратегічних секторів: високотехнологічні види промислової діяльності, середньовисокотехнологічні види промислової діяльності, пошта та телекомунікаційний сервіс, фінансові ма страхові послуги, інші ділові послуги. Окрім базових до стратегічно важливих секторів економіки OECD також відносить соціально-значимі види економічної діяльності суспільства: освіта, охорона здоров'я тощо.

За часткою у структурі економіки стратегічних секторів оцінюється реальний рівень розвитку економіки кожної країни, а за динамікою зміни частки стратегічних секторів можна відстежувати тенденції розвитку економік та їх аналіз при більш глибокому вивченні структури частки стратегічних секторів.

Вказані теорії та методології фіксують наслідки змін у структурі економіки і лише констатують тенденції, та за допомогою нормативно-цільових прогнозів дають змогу формувати коротко- та середньострокові прогнози змін структури та тенденції розвитку економік.

Ці та інші теорії розвитку економіки стали основою аналізу пропорцій національних економік, що грунтуються на прийнятій економічним співтовариством Міжнародній стандартній галузевій класифікації видів економічної діяльності (ISIC) [10, c. 80].

Структура економіки України формувалась під впливом унікальної комбінації факторів як економічного так соціального $i$ політичного характеру, щчо на сьогодні сформували свій комбінований вплив важливість якого сліо оцінювати наступним чином.

Унікальна, компактно розташована територія України зі сприятливими природно-кліматичними ресурсами, вигідним географічним та економікогеографічним положенням та розташуванням в межах різноманітних тектонічних структур, що представлено більшістю відомих у світі корисних копалин, які використовуються людством, та найоптимальнішими для розвитку агропромислового виробництва природно-кліматичними ресурсами, мають величезне значення для розвитку економіки України та формування її структури. 
На території України проживають понад 45 мільйонів високоосвічених, працелюбних людей, що $\epsilon$ основою для розвитку економіки та суспільства, а багатовіковий досвід населення у сільськогосподарському та промисловому виробництвах $€$ вкрай важливим чинником розвитку економіки України та удосконалення ㄲï структури.

Україна межує з одним найбільших у світі ринків та виробничим регіоном - Свропейським Союзом, що після вступу у дію договору про зону вільної торгівлі забезпечить розширення ринку для української продукції з одного боку, та конкуренцію/сприяння, з іншого боку, матиме наслідок у розвитку галузей стратегічних секторів економіки.

Негативним чинником слід вважати історичне минуле, у якому економіка України була частиною економіки іншої країни і розвивалась на неконкурентній основі, забезпечуючи розвиток стратегічних секторів іншої економіки та залишаючись 3 незавершеними циклами виробництв після здобуття Україною незалежності у 1991 році. Ці тенденції посилились в 2014 - 2015 роках у зв'язку 3 агресивними діями Російської Федерації, 3 якою Україна підтримувала кооперативні виробничі відносини, що базувались на спільній участі у виробництві високотехнологічних видів продукції в авіаційній, аерокосмічній галузях, транспортному машинобудуванні, оборонній галузях.

Несформованість завершеної структури економіки та тривале падіння виробництва в галузях переробної промисловості на фоні нещадного використання потенціалу галузей видобувної та сировинної галузей промисловості, практична відсутність інвестицій у модернізацію фондоємних галузей та надмірна концентрація виробництва в сировинних галузях призвели до скорочення ВДВ, як сталої тенденції.

Окрім того, слід відзначити процеси неекономічного характеру, що протягом більш ніж 2 десятиліть здійснюють негативний вплив на розвиток структури економіки України. По-перше, перехідний період від соціалістичного ладу до ринкової економіки супроводжувався неконтрольованим перерозподілом власності і фінансових потоків до рук дуже обмеженого кола осіб, зацікавленість яких проявлялась лише у максимізації власних прибутків за всяку ціну, без врахування реальних можливостей та потреб держави і суспільства. Такі олігополії для входження в світові та регіональні товарні ринки використовували будь-які можливості, у тому числі, і демпінгове ціноутворення. У якості схем та механізмів було використане трансферне ціноутворення, що передбачало використання схем та юрисдикцій для максимізації прибутків нових власників. Це приводило до мінімізації ВДВ та вимивання з бюджету України колосальних коштів на відшкодування експортного ПДВ, що негативно впливає на соціальну та економічну політику України, обмежуючи фінансові можливості забезпечення підтримки високотехнологічного експорту (аерокосмічна промисловість, літакобудування, кораблебудування, надання транскордонних послуг у транспортній сфері та будівництві).

Політичний чинник як результат непрозорої приватизації та високого рівня концентрації на фоні відсутності професійного та мотивованого управління економікою призвів до зниження основних показників, передбачених методологією OECD $з$ 16,7\% у 2000 році (рівень Греції - 17,1\%; Мексики - 18,4\%) до 13,5\% у 2014 році. Наразі ситуація продовжує погіршуватись на фоні відсутності будьяких серйозних змін в економічній політиці країни.

Наслідком негативних тенденцій у розвитку економіки є також соціальний та освітній фактори. Низький рівень індивідуальних доходів, низький рівень продуктивності праці, деградація галузей освіти та охорони здоров’я, призвели до зниження рівня професійної підготовки та відсутності висококваліфікованих трудових ресурсів. Такі тенденції різко обмежують можливості розвитку економіки, а низький життєвий рівень підвищує міграційні очікування населення, особливо висококваліфікованого, у працездатному віці. За даними соціологічних досліджень більш ніж 25\% населення у віці від 25 до 40 років розглядають можливість еміграції в країни 3 більш високим рівнем життя та доходами. Масові міграції населення на фоні негативного сальдо приросту населення веде до старіння населення та скорочення чисельності трудових ресурсів, що негативно впливає як на структуру економіки, так i на можливості інвестування в економіку України, через брак кваліфікованих кадрів.

Використовуючи методику ISIC та інші підходи аналізу структури економіки слід зазначити, що у порівнянні з іншими країнами (згідно класифікації країн, прийнятої ООН) у структурі економіки України, як і у розвинених країн переважає сфера послуг у ВДВ, що становить 62,85\%, і є співставним 3 аналогічними показниками розвинених країн, таких як США - 78,08\%; Японія - 71,26\%; Швеція - 71,25\% (станом на 2010 рік) [1, с. 30]. Разом 3 тим Україна відрізняється від інших країн високою часткою сільськогосподарського виробництва у структурі ВДВ, що в декілька разів перевищує аналогічні показники розвинених країн - 7,80\%. Такий показник $\epsilon$ характерним для країн що розвиваються (Аргентина, Чилі) та густонаселених країн (Китай, Індія).

Важливим $\epsilon$ аналіз структури промислового виробництва у загальній структурі економіки країни. За цим показником Україна формально знаходиться серед розвинених країн. Але статистичні дані свідчать лише про формальність даного показника. Оскільки валові показники промислового виробництва значно відстають від аналогічних показників розвинених країн. Ця проблема вимагає окремого дослідження причини такого стану.

Для розуміння ситуації приймемо за основу показники Деркомстату України та інформацію отриману з відкритих джерел, таких як офіційного сайту ЦРУ - Country Fackbook CIA, де тільки дані про ВВП України відрізняються більш ніж у рази. 
Різниця в даних пояснюється просто. ЦРУ США враховує рівень офіційної та тіньової економіки, в той час як Державний комітет статистики України використовує лише офіційні дані. За оцінками міжнародних експертів понад $60 \%$ економіки України знаходиться в тіні. Така ситуація становить реальну загрозу національній безпеці України, оскільки не дозволяє реально оцінювати та керувати економічним потенціалом, формувати стратегії розвитку та здійснювати управління фінансовою та фіскальною системами країни в повній мірі. Відсутність об'єктивної інформації та впливу на функціонування тіньової економіки призводить до прийняття хибних рішень та не дозволяє прийняти рішення на державному рівні щодо об'єктивного управління економікою на державному рівні з метою сталого розвитку країни. Разом 3 тим надзвичайно високий рівень тінізації економіки формує внутрішні та зовнішні загрози, класифіковані у роботах Подмазко О. М. [8, с. 145].

Розробка стратегічних напрямків розвитку та змін у структурі економіки України неможлива без об'єктивних базових статистичних даних 3 урахуванням усіх показників, як тіньової економіки, так і офіційних даних.

В основу моделювання середньострокової та дострокової перспектив змін структури економіки України покладено класифікацію ISIC, тобто укрупнені сектори економіки: сільське господарство, промисловість, сфера послуг. За даними Державного комітету статистики України, тенденції розвитку укрупнених секторів співпадають з загальносвітовими тенденціями, тобто неухильно поступово зростає частка сфери послуг у структурі i ВДВ, i ВВП. Протягом останнього десятиліття спостерігалось незначне скорочення виробництва в сільськогосподарському секторі, що протягом останніх 5 років змінилось на незначне зростання на фоні скорочення промислового виробництва.

За даними, опублікованими на офіційному сайті ЦРУ США, співвідношення між основними секторами економіки виглядає наступним чином на 2014 рік: сільське господарство - 12,1\%; промислове виробництво - 29\%, сфера послуг - 59,9\%.

За структурою зайнятості, співвідношення між основними секторами виглядає так: сільське господарство - 5,6\%, промислове виробництво $26 \%$, сфера послуг 68,4\% [13, с. 5].

Аналогічні тенденції відображають показники i української статисти. Але вкрай важливим є спостереження тенденцій, що спостерігаються всередині укрупнених секторів 3 огляду на співвідношення у їх структурі галузей та їх територіальні інтерпретації.

Сільське господарство. Розвиток галузі має три основні чинники, що передували іiі прискореному розвитку та ролі у структурі економіки: сприятливі природно-кліматичні ресурси, висока густота сільського населення, багатовікові історичні передумови. Галузь протягом останніх 20 років пережила процеси реформування, фактичне знищення колгоспного виробництва, зародження та формування фермерського руху, розпаювання земель сільськогосподарського призначення, зростання швидкими темпами концентрації виробництва та, фактично, технологічної революції в деяких галузях сільськогосподарського виробництва.

Поштовхом у розвитку сільського господарства стало зниження світового виробництва продовольства та сприятлива кон'юнктура регіональних та світових ринків сільськогосподарської продукції, особливо рослинницької: зернові (пшениця, ячмінь, кукурудза), ефіроолійних культур (насіння соняшника, ріпаку). Застосування індустріальних технологій у рослинництві та тваринництві призвело до швидкої концентрації виробництва в великих підприємствах, які застосовують найсучасніші технології, що веде до скорочення реальних затрат на виробництво та скорочення зайнятих в галузі. Тенденції в розвитку галузі фактично знищили внутрішню конкуренцію та призвели до розподілу сфер впливу в межах усієї країни. Другим негативним наслідком надмірної концентрації виробництва $є$ негативні тенденції в розвитку системи розселення в сільській місцевості, фактична відсутність підтримки та розвитку інфраструктури сільської місцевості. Вплив аграрного лобі на політику України в сфері сільськогосподарського виробництва веде до перерозподілу ВДВ галузі між крупними виробниками. Разом $з$ тим, для вирішення проблем сільської місцевості необхідні значні капіталовкладення, яких в державному бюджеті не вистачає. 3 нашої точки зору, розвиток сільської місцевості повинен здійснюватися за рахунок перерозподілу доходів до місцевих бюджетів для розвитку сільськогосподарських територій.

Розвиток сільськогосподарського виробництва необхідно розвивати шляхом вертикальноінтегрованих галузей, що виробляють кінцеву продукцію, придатну для споживання кінцевих споживачем. 3 огляду на низьких рівень ВДВ, що генерується в галузі їі розвиток має розвиватись у таких напрямках:

- Забезпечення стратегічної продовольчої безпеки країни та її сталого розвитку у тісному зв'язку з збереженням навколишнього середовища;

- Зважаючи на великі об'єми виробництва та сприятливі економічні та природно-кліматичні умови галузь має залишатись однією 3 ключових у міжнародній торгівлі України в середньостроковій перспективі для підтримки зовнішньоторговельного балансу країни з поступових зниженням долі галузі в структурі економіки за рахунок збільшення об'ємів виробництва в інших секторах.

Промислове виробництво. У структурі економіки вказаний доля сектора складає 29\%. У порівнянні з іншими країнами доля промисловості відповідає загальносвітовим тенденціям, однак галузева та територіальна структури промисловості України не відповідають світовим тенденціям щодо оптимального співвідношення секторів.

У галузевій структурі переважають видобувні галузі (первинний видобуток, збагачення, та виробництво напівфабрикатів) чорних та 
кольорових металів, важке машинобудування (виробництво засобів виробництва та гірничорудної та металургійної промисловості, верстатобудування тощо, транспортне машинобудування (аерокосмічна галузь, вагонобудування, локомотивобудування, кораблебудування, літакобудування, виробництво та ремонт автомобільної техніки, енергетичне машинобудування тощо). Важливою часткою у машинобудуванні України, що дісталась їй в спадок була оборонна промисловість. Протягом останніх 20 років відбулись рушійні зміни в структурі промисловості України, що вплинули на галузеву структуру, але практично не торкнулись територіальної. Зміна оборонної стратегії призвела до практичного занепаду оборонної промисловості, Відсутність замовлень та конкурентоспроможності при переході до ринкової економіки практично знищили кораблебудування, та аеро-космічну галузь, негативно впливали на машинобудування по виробництву засобів виробництва та сільськогосподарське машинобудування. Світовою тенденцією промисловості в структурі економіки є найвищий рівень ВДВ, тому при відносно невисокій долі в структурі, сектор виробляє левову частку ВДВ, забезпечуючи розвиток країни.

Аналіз структури експорту дає змогу реально оцінити рівень розвитку країни за структурою іiі експорту. В експорті розвинених країн переважають високотехнологічні продути, хоч існують певні виключення (Австралія). В структурі українського експорту біля половин, у вартісному відношенн,і складає продукція машинобудування. Серед галузей ключове значення мають енергетичне машинобудування (включаючи виробництво КВП та автоматики), транспортне машинобудування (виробництво та ремонт авіаційної техніки та їі компонентів (двигунів). В цій галузі Україна займає дуже важливу нішу, у якій вона $є$ конкурентною та інноваційною, що поряд 3 наявністю повного циклу виробництва у літакобудуванні забезпечує конкретність української промисловості.

Другим важливим кроком у напрямку збільшення конкурентоспроможного виробництва $€$ виробництво у галузі транспортного машинобудування (автомобілебудування), з ринками Свропи та інших країн. Цьому слугує Договір про Асоціацію України 3 ЄС. Україна в силу географічного положення, вартості трудових ресурсів та наявності відповідних галузей металургії і хімічної промисловості може стати територією або «фабрикою» масового тиражування високотехнологічної продукції для ринку Європейського Союзу, Близького Сходу, Північної Африки та Передньої Азії. Перевагу слід віддавати високотехнологічним, наукоємним галузям промислового комплексу. наряду 3 тим, чорна та кольорова металургія повинна зазнати суттєвих змін перетворюючись 3 галузей, що виробляють прості профілі та інші необхідні, але не технологічні види продукції, до високотехнологічних виливок та виштамповок продукції, що виготовляються з сортів металу з заданими якостями, тобто перспектива за якісною металургією.

Перспективу має також завершеність виробничих циклів сільського господарства харчова промисловість, де створюється основна частка ВДВ. Україна має хороші перспективи у виробництві харчових олій, продукції тваринництва (молочна та м'ясопереробна галузі) для забезпечення внутрішнього ринку та розширення експортних можливостей. Розвиток промислового виробництва у структурі економіки має здійснювати тиск на долю сільського господарства щодо їі скорочення.

Сектор послуг протягом останніх 2 десятиліть розвивався швидкими (випереджаючими) темпами, забезпечуючи кінцевого споживача, життєво важливі напрямки соціально-економічного комплексу країни та надаючи транскордонні послуги, сприяючи зростанню експорту. В секторі послуг зайнято найбільшу кількість трудових ресурсів i, незважаючи на невисокий рівень ВДВ, ключовою перевагою сектора $є$ динамічність у часі надання послуг та невисока фондоємність галузі (переважно). Галузь тісно пов'язана 3 розселенням населення на території України та видами послуг, що надаються. Деякі послуги мають чітко виражену територіальність (туристичні, спеціалізовані медичні, освітні, торгові послуги), інші не мають чіткої територіальної прив'язки. До них належать транспортні, обмін інформацією тощо.

Вказаний сектор в перехідний період почав відігравати ключову роль в структурі економіки України, оскільки більша частина підприємств належать до групи малих і середніх, які прийняли на себе найбільше навантаження та забезпечили зайнятість трудових ресурсів. що масово вивільнялись 3 промислового сектора, в кризові періоди розвитку економіки України.

Зважаючи на потенційні можливості України у розвитку внутрішнього та в їзного туризму, розвитку ресторанного бізнесу, курортно-лікувальної сфери та інших галузей, сектор має добрі перспективи розвитку та нарощування валових об'ємів надання послуг.

Висновки і перспективи подальшого розвитку. Структура економіки України розвивається у відповідності до законів ринкової економіки та загальних тенденцій світового розвитку. У запропонованих напрямках оптимізації виділяються напрямки пов'язані з вертикальним розвитком структури сільського господарства, що забезпечувало б виробництво сировини для харчової промисловості та збільшення виробництва кінцевої продукції, що має вищу валову добавлену вартість.

Промисловий сектор протягом останніх десятиліть зазнав значних змін, в результаті яких постійно зростала доля добувної та скорочувалась доля переробної галузей та машинобудування. Для забезпечення позитивних змін в структурі необхідним $\epsilon$ створення умов на державному рівні для залучення прямих інвестицій в машинобудування та розвиток масового виробництва на території України продукції високотехнологічних видів машинобудівної продукції для внутрішнього споживання та експорту. 
Сфера послуг теж вимагає якісних змін у своїй структурі у бік надання високоякісних туристичних, освітніх, медичних послуг конкурентного рівня для збільшення як внутрішнього, так і в’їзного туризму. Цей сектор вимагає пріоритетного розвитку соціальної, виробничої та транспортної інфраструктури.

\section{References:}

1. Bìlobrova T. O., Bazpvluk N. G., Galuzeva struktura ekonomìki âk peredumova formuvannâ nacìonal'noï konkurentospromožnostì: mìžkraïnovì porìvnânnâ [Sectoral structure of the economy as a prerequisite for the formation of national competitiveness: a cross-national comparison]. Naukovij visnik Poltavs'kogo universitetu ekonomiki i torgivli [Scientific Bulletin of Poltava University of Economics and Trade], 2012, Vol. 3 (54), pp. 28 -31. (In Ukrainian).

2. Čajka Û. Mehanìzmi strukturnogo rozvitku nacìonal'noï ekonomiki [Mechanisms of structural development of the national economy]. Visnik KNTEU [Bulletin of Kyiv National University of Trade and Economics], Vol. 3/2011, pp. 30-41 (In Ukrainian).

3. Cherkass N. Technological Exports and Dynamics of Ukrainian Economic Growth. Access mode: http://www. kneu.kiev.ua/journal/eng/article/2006_1_Cherkas_eng.pdf

4. Economic Reform Agenda for Ukraine. German Advisory Group (Ricardo Giucci, Robert Kishner, George Zachmann). Berlin/Kyiv, March 2014. Access mode: https://www.google.com.ua/?gfe rd=cr\&ei=16BDVqDoJ8HFZN myiKAF\&gws_rd=ssl\#q=Economic+reform.+Agenda+for+Ukraine+German+Advisory+Group

5. International Standard industrial Classification (ISIS), Revision 3. Access mode: http//unstats.un.org/unsd/ registry/regcst.asp?CI=14\&Lg=1

6. Lotoš O. O. Galuzeva struktura ìnvesticìj v ekonomì̀ì Ukraïni [Investments in the Ukrainian economy: sectoral structure]. Ekonomika ì upravlìnnâ [Economics and management], 2014, Vol. 1, pp.38-43. (In Ukrainian).

7. Pirìg O. V. Adaptaciâ strukturi nacìonal'noï ekonomìki Ukraïni do vimog postìndustrìal'nogo suspìl'stva [Adapting the structure of national economy of Ukraine to the requirements of postindustrial society], pp. 93-103. Access mode: http//www.ena.lp.edu.ua -2013. (In Ukrainian).

8. Podmazko O. M. Vpliv tìn'ovoï ekonomiki na zagrozi ekonomičnoï bezpeki kraïni. Transformaciâ ta rozvitok ekonomičnih sistem [The effect of the shadow economy to the threats to national economic security. Transformation and development of economic systems], pp. 142-151. (In Ukrainian).

9. Savčenko K. V. Analìz tehnologìčnoï strukturi ekonomìki Ukraïni v kontekstì zabezpečennâ ekonomičnoï bezpeki deržavi [The analysis of technological structure of Ukrainian economy in the context of ensuring national economic security]. Mehanizm regulûvannâ ekonomiki [The mechanism of economic regulation], 2009, N. 4. T.1, pp.171-177. (In Ukrainian).

10. Šinkarenko T. P. Strukturnì zmìni v ekonomì̀ì Ukraïni: porìvnânnâ z zagal'nosvìtovimi tendenciâmi [Structural changes in the economy of Ukraine: comparison with global trends]. Ekonomika i prognozuvannâ [Economics and forecasting], 2006. Access mode: http://dspace.nbuv.gov.ua/bitstream/handle/123456789/19801/06--Shynkorenko. pdf?sequence=1 (In Ukrainian).

11. Skìrka N. Â. Galuzeva struktura nacìonal'noï ekonomìki ì naprâmki ïï optimìzacii [Sectoral structure of the national economy and ways of its optimization]. Efektivna ekonomika [Efficient economy], 2013, Vol. 9, pp. 45 - 49. (In Ukrainian).

12. Titarenko L.M. Struktura zrušen' nacìonal'noï ekonomìki v umovah êvroìntegraciï [Structural changes of national economy in conditions of European integration]. Visnik ONU im.Mečnikova [Bulletin of Mechnikov Odessa National University], 2013, T. 18, Vol. 3/3 pp. 108-111. (In Ukrainian).

13. Ukraine. Factbook. Access mode: https:/www.cia.gov/library/publications/the-world-factbook/geos/up.html

14. Ukraine's Economic Challenges (In depth analysis) By Naja Benzen. European Parlamentary Reseach Service. Access mode: http://www.europarl.europa.eu/RegData/etudes/IDAN/2015/559497/EPRS_IDA(2015)559497_EN.pdf

15. World Economic Situation and Prospects 2015. United Nations. New York, 2105. Access mode: http://www. un.org/en/development/desa/policy/wesp/wesp_archive/2015wesp_chap1.pdf 